\title{
IMPROVING PEDAGOGICAL CONDITIONS FOR DEVELOPING A RESPONSIBLE ATTITUDE TO VIRTUAL LEARNING IN FUTURE TEACHERS
}

Ovhunov Ikboljon Abdunabievich - Head of the Department of Informatics Teaching Methods, Andijan State University.

Rakhmonov Omadjon Mamasidiq ugli - Lecturer at the Department of Computer Engineering, Andijan State University

Aliyeva Gulzira Akbaraliyevna - Teacher of the Department of Informatics Teaching Methods, Andijan State University.

\section{ABSTRACT}

In the article the following issues are researched: the implementation of interdisciplinary links between the disciplines in the field of informatization of education with informatics and ICTs, pedagogy, psychology, as well as with the core disciplines for each teacher specialty; the definition of the place of the disciplines in the field of education informatization in the SES HPE for teacher specialties and directions; the realization of consistency and systematicness of university and postgraduate training in the use of ICTs in teaching.

Keywords:

ICT, informatization, implementation, pedagogical assessment, androgogical model

Article Received: 18 October 2020, Revised: 3 November 2020, Accepted: 24 December 2020

\section{INTRODUCTION}

The modern stage of mass global communication society development is characterized by the rapid development of information and communication technologies (ICT), used in many areas of human activity, including pedagogical. Of particular importance is the informatization of education, which we will consider as a purposefully organized process of providing the sphere of education with methodology, technology and practice of creation and optimal use of scientific and pedagogical, educational and methodological developments, focused on the implementation of the possibilities of information and communication technologies used in comfortable and health-saving conditions [1].

One of the main directions of informatization of education is the use of ICT tools in order to improve teaching methodological systems that focus on the development of learners' intellectual potential under the conditions of informatization of society; the implementation of information activity and information interaction for educational purposes; educational management, including in terms of local and global computer networks; psychological and pedagogical diagnostics of student learning outcomes based on computer testing The use of ICTs occurs under conditions of their continuous technical and technological development, as well as the development of a theoretical basis for the informatization of education, which predetermines the need for training and continuous, systematic professional development of teachers in the implementation of ICT capabilities in pedagogical activity[2].

These studies and the practice of using ICT tools in the educational process of schools indicate that the level of training of pedagogical staff determines the effectiveness of the implementation of psychological and pedagogical developments based on the implementation of ICT capabilities aimed at the development of the student's personality, intensification and intellectualization of learning activities, using modern methods of collecting, processing and transmitting information. 
Due to the fact that the current approaches to the training of subject teachers do not fully cover the impact of the process of informatization of education on pedagogical activity and do not fully reveal the issues of consistency between the university and post-graduate training, we turn to studies devoted to the theoretical foundations of the professional activity of teachers, and the development of continuing professional education, in particular the teacher training.[3]

The system of continuous teacher training in the use of ICTs in professional activity is defined as a set of interconnected and interacting components that form a certain integrity and unity: goals, content, means, forms and methods of training, education and development of students and teachers at the stages of university and postgraduate professional teacher education, including personal self-improvement.

In this context, we consider the implementation of the system of continuous teacher training in the field of education informatization in stages. The university stage of training implies purposeful training of teacher students in the application of ICT tools, including theoretical and practical training, pedagogical practice, which provides the necessary foundation for the further development of the subject teacher in the aspect under study. Postgraduate training is characterized by the development of the staff potential of the school in the aspect of both periodic training of subject teachers in the system of professional development of educators in the field of information and education, and training in a specific information and communication environment of the school (in-school training). For practical realization of intraschool training which affects many organizational links of school, including methodical and organizational interaction between teachers, methodical associations of school, administration, etc., development of methodical approaches to preparation of organizers of informatization of education in this aspect is required [4].

However, the development of unified scientific and methodological approaches to the continuous training of subject teachers in the use of ICTs in their professional activities remains an unsolved issue.

Taking into account the above-mentioned, we shall formulate a group of contradictions between:

- the need for subject teachers' training in the field of: general approaches to improving the educational process based on the implementation of ICT capabilities; development, application of distributed information resource of educational purpose; creation, use of electronic means of educational purpose, as well as implementation of psychological and pedagogical assessment of their quality; organization of psychological and pedagogical diagnosis and testing, assessment of knowledge and skills of students using automation means; legal and regulatory issues related to the use of ICT in education

- the existing structure of subject teacher training in the use of ICTs in pedagogical activities, which does not fully take into account general approaches to implementing information activities and information interaction based on automation tools, the specifics of teaching methods of the subject using ICTs, the specifics of the subject area, the features of the informatization process at school and the need for continuing teacher training, focused on general approaches, $\mathrm{s}$

- the increased requirements for subject teachers in the field of improving the methods of teaching in the subject in terms of the implementation of didactic capabilities of ICTs, the use of automation in the management of the educational process, the production of professionally significant information in terms of information activities and information interaction, including in local and global networks, and the lack of professional preparedness of subject teachers in the field of education informatization

- the need for systematic improvement of the professional level of teachers in the implementation of the main directions of informatization of education in the continuous technical and technological improvement of the information and communication environment of 
schools and the insufficient level of existing scientific and methodological approaches to the training of specialists in the organization of inschool training of subject teachers to use ICT tools in professional activities.

The formulated group of contradictions defines the research problem - improving the content, structure, methodological approaches to continuous training of subject teachers in the use of ICT tools in professional activities.

\section{METHODS}

The topicality of the research topic is determined by the need for: theoretical justification and development of the content of teachers' continuous training of subject teachers adequate to the main directions of informatization of education and the structure of pedagogical activity; development of a structure of continuous training that takes into account general approaches to implementation of information activity and information interaction of educational purpose and specificity of the educational discipline; improvement of qualification characteristics in the aspect of professional

Based on the goal and hypothesis of the study, the research objectives were formulated:

1) to analyze the current state of training and professional development of teachers in the use of ICT tools in professional activities;

2) to theoretically justify and formulate the principles of continuous training of subject teachers in the use of ICT tools in professional activity;

3) theoretically justify and develop a qualification characteristic of subject teachers in terms of changes in the content of the components of the professional activity of the teacher in conditions of the use of ICT tools in the educational process;

4) theoretically justify the structure and develop the content of teachers' continuous subject teacher training in terms of the implementation of the main directions of informatization of education;

5) develop methodological approaches to undergraduate and postgraduate training of subject teachers in using ICT tools in professional activities

6) develop meaningful aspects of training of organizers of informatization of education in the theory and practice of the organization of inschool training of subject teachers, implemented in the information and communication environment of the school;

7) experimentally test the level of students' and teachers' mastery of pedagogical activities using ICT tools.

To solve the set tasks the following research methods were used: theoretical analysis and generalization of the provisions of psychological and pedagogical science, computer science, the theory of pedagogical experiment; study and analysis of the experience of teaching computer science and information technology, various disciplines using computer science methods and ICT tools, as well as disciplines of psychological and pedagogical orientation; analysis of state educational standards of higher professional education for pedagogical specialties and directions, curricula and manuals for training and retraining of subject teachers in computer science and information technology, as well as the use of ICT tools in education; observations, interviews, questioning; conducting classes in the information and communication environment of the institution; educational experiment, processing and theoretical analysis of the experimental results.

Scientific novelty of the research is as follows: formulated the main content areas of continuous training of subject teachers in the use of ICT tools in professional activities and developed the content of basic training of subject teachers in terms of implementation of training in general issues of informatization of education, training in teaching methodology and the use of ICT tools in the subject area; identified methodological approaches to the organization of university and post-graduate stages of continuous training of subject teachers in the use of ICT tools in professional activities; developed the content and methodological aspects of training of school IT 
specialists in the implementation of in-school training of subject teachers in the use of ICT tools in the functioning of the information and communication environment of the school.

The proposed methodological approaches can be used in the training of students of pedagogical universities, pedagogical colleges, colleges of different specialties, as well as in the retraining of subject teachers and leaders of secondary schools, teaching staff of pedagogical universities, etc.

The research was carried out within the research work of Andijan State University of Uzbekistan. During research we studied the degree of development of the problem in foreign science, analyzed philosophical, culturological, pedagogical, psychological and technical literature, studied domestic and foreign experience of education informatization, analyzed main directions of informatization of educational process at school and teachers' training experience in ICT usage in professional activity at different stages of continuing education.

\section{CONCLUSION}

An analysis of the current state of teacher training and professional development in the use of ICTs in professional activities has identified the features of the stages of training: the higher education stage is the formation of readiness of students of all specialties to work in schools in the conditions of informatization of education; at the postgraduate stage the professional development and additional training of teacher-subjects in the field of education informatization taking into account the existing teaching experience and the postgraduate stage. The analysis showed that at present the existing potential of information and communication technologies in the educational process of school and higher education institution is not realized enough; the continuity of higher and postgraduate education is not fully realized; interdisciplinary links between the disciplines in the field of information and education, computer science and ICTs, pedagogy, methodology, specialized disciplines, psychology, and also the specialized disciplines are not taken into account. Unified approaches to the implementation of the training of subject teachers at different stages, which take into account the impact of the process of informatization of education on teaching activities, ensuring systematic training adequate to the continuous technical and technological development of information technologies and communications based on local and global computer networks and the development of the theoretical base of informatization of education were not developed.

The following external (progress in science and technology, lack of readiness of most subject teachers to use ICTs) and internal (the objectively existing system of training and retraining of subject teachers in the use of

the identification of didactic capabilities of ICTs; teacher motivation for the use of ICT tools in their teaching activities) prerequisites for continuous training of subject teachers in the field of informatization of education.

The concepts of lifelong learning and the system of lifelong learning of teachers in the field of ICT tools in professional activities were defined.

Theoretically justified and formulated principles of continuous training of subject teachers in the use of ICT tools in professional activities: continuity of training (correlation of training content at the postgraduate stage with university programs in the use of ICT tools in professional activities); predictability of training (reflection in training programs of modern achievements of scientific and technological progress, pedagogy, psychology, informatization of education and other sciences in the aspect of prospective use of ICT tools in education); commonality of approaches to information activities and information interaction in pedagogical activities (study of Integrate theoretical issues in the content, methods and organizational forms of education and upbringing in the contemporary information society and the issues of solving practical pedagogical problems in the use of ICTs in professional activities; the inversion and 
variability of training (identifying common for all teachers (regardless of profile) the content of training in general issues of informatization in education, on the one hand, and on the other, the need for training that reflects the characteristics and implementation of ICT capabilities in a particular subject area); integration of training in the implementation of the main directions of informatization of education (the inclusion of issues in the training content in the use of ICTs in professional activity of the teacher); the development of a plan for the development of the ICT

Theoretically justified and clarified the content of the gnostic, planning, constructive, organizational and communicative components of teachers' activities under the conditions of informatization of education. It is shown that the predictive component is connected with obtaining and analyzing information about the educational process in order to identify problems which require the use of certain ICT tools and the development of teacher motivation to use ICT tools in their professional activities. The design component, in turn, relates to the teacher's identification of specific psychological and pedagogical goals and objectives for the use of ICT tools in pedagogical activity. The constructive component reflects the teacher's activity in planning the educational process under conditions of ICT application. The organizational component reflects the actual implementation activity in the creation, preparation and use of ICT tools for teaching, for analyzing results of knowledge acquisition using computer-based testing software, for automating processes of information and methodological support and organizational management of an educational institution. The communicative component ensures the interaction of all participants in the educational process in the information and communication environment of the school realized on the basis of local and global networks.

The subject teacher's qualification profile in the use of ICTs, which specifies types of professional activity in the context of informatization of education in terms of using, improving and creating methodological teaching systems (in the subject area) based on ICTs; training students in the necessary skills to use ICT tools in the subject area; expert assessment of the quality of ESSs; use, design and development (using software tools) of ESSs (fragmented organization of information interaction (including educational) on the basis of computer networks (local, global); management of the learning and educational process based on the automation of information and methodological support; psychological and pedagogical diagnostics of the level of learning, progress in learning on the basis of computer testing methods for monitoring and evaluating student knowledge; development of students' own creative potential and potential necessary for further self-learning, selfdevelopment and self-realization in the conditions of

Theoretically substantiated and formulated content lines for continuous training of subject teachers in the use of ICT tools in pedagogical activities: theoretical foundations of informatization of education (invariant direction); psychological and pedagogical foundations of informatization of education (invariant direction); methods of teaching the subject discipline using ICT tools (variative direction); use of ICT tools in the subject area (variative direction); information interaction in conditions of functioning of local and global computer networks, the potential of a distributed information resource (invariant direction, variability can be manifested in the specification of the resource of educational purpose); pedagogical-ergonomic conditions of safe and effective use of computer technology, informatization and communication means (invariant direction of training, variability is provided when teaching the assessment of content-methodological significance of ESS); possible negative consequences of the use of ICTs and measures to prevent these consequences (invariant direction); automation of information and methodological support of the educational process and organizational management of an 
educational institution based on ICTs (invariant direction, variability is shown depending on the automation tool used); information and communication environment of the educational institution (at the stage of higher education is invariant, at the postgraduate stage it is shown in variations of the content and methodological significance of ESSs)

The implementation of the content lines of training determines its complexity in psychological and pedagogical, methodological, technical and technological, design-ergonomic and legal aspects.

The content areas of continuous training identified in the study determine its structure: invariant training in general issues of informatization of education; variable training in the methods of teaching discipline with the help of ICTs and the use of ICTs in the profile subject area; additional training in the organization of the informatization process in school.

Methodological approaches to university teacher training that ensure: focus of student training on mastering general patterns and trends of future professional activities in the context of informatization of education; mastering students' future practical activities in the use of ICTs based on contextual learning; use of ICTs in the learning process of the university, including the use of educational resources based on the implementation of the capabilities of information and communication environment of the university; of The curricula for the invariant training of inservice teacher training discipline "Use of ICTs in Teacher's Work" were developed, as were the curricula for the variative training discipline "Methods of Teaching Subjects Using ICTs" (using the ICTs to train physics teachers as an example). (example: training of a physics teacher), and "Using ICTs in a Subject Area" (example: training of a mathematics teacher). Using ICTs in the Subject Matter (based on the example of training a mathematics teacher).

The methodological approaches to the postgraduate teacher training were developed to ensure: mastery of practical activities in the use of
ICT tools based on the pedagogical experience of the subject teacher; differentiation by the level of initial teacher training and the profile of subject teacher training; continuity of the learning process through periodic professional development in SPKRO and systematic in-school training; orientation towards independent information and e-learning. The basic functions of the postgraduate preparation of the teacher-subject in the field of education informatization are proved: compensatory (filling of missing knowledge, abilities, skills in the field of education informatization), adaptive (preparation of the teacher-subject to changing conditions of realization of the professional activity in the conditions of education informatization) and developing (development of personal and professional abilities and needs of the teachersubject in the field of ICT means when solving professional problems).

The concept of in-school teacher training in the field of informatization of education is defined. The content of the discipline "In-school training of subject teachers in the field of informatization of education" for the training of the organizers of informatization of education was developed: goals, objectives and content of inschool training of subject teachers in the field of informatization of education; psychological and pedagogical basics of in-school training of subject teachers in the field of informatization of education (features of adult education; pedagogical and androgogical models of training; psychological androgogical diagnosis of students); organization of in-school training in the field of informatization of education (creation of conditions of in-school training; joint planning of training; diagnostics of the level of learning of students and their progress in learning; assessment of the learning process; correction of curriculum and learning process); evaluation of results of inschool training of subject teachers in the use of ICT tools in professional activity.

\section{REFERENCES:}


[1] Artyushkin O.V. Organizational and pedagogical conditions for the formation of information culture of a student's personality by means of informatization: Abstract of a dissertation. Novokuznetsk, 2005.

[2] Bagautdinova N.G. The innovative potential of higher education: Analysis and evaluation. Moscow: Economics, 2002.

[3] Bulgakov M.V., Pushkin A.E., Fokin S.S. Computer technologies in higher education / Ed. Col .: A.N. Tikhonov, V.A. Sadovnichy and others - Moscow. Moscow State University, 1994. P. 147-152.

[4] Ovkhunov I.A. Responsible attitude towards virtual teaching in future pedagogues. European Journal of Research and Reflection in Educational Sciences Vol. 8 No. 12, 2020

[5] Okhunov I.A. IMPROVEMENT OF PEDAGOGICAL CONDITIONS FOR DEVELOPING RESPONSIBLE ATTITUDE TO VIRTUAL REALITY IN FUTURE TEACHERS Bulletin of Science and Education 2020 